\title{
Antibacterial, cytotoxic and antioxidant activity of chloroform, $n$-hexane and ethyl acetate extract of plant Coccinia cordifolia
}

\author{
Israt Jahan Bulbul ${ }^{1 *}$, Laizuman Nahar $^{2}$, Mahmuda Haque ${ }^{1}$ \\ ${ }^{1}$ Assistant Professor, Department of Pharmacy, Southeast University Banani, \\ Dhaka-1213 \\ ${ }^{2}$ Lecturer, Department of Pharmacy, Southeast University Banani, Dhaka-1213
}

\begin{abstract}
The main aim of this study was to find out the antibacterial, cytotoxic and antioxidant activity of chloroform, n-hexane and ethyl acetate extracts of Coccinia cordifolia (Family: Cucurbitaceae). Disc diffusion technique was used for in vitro antibacterial screening against gram positive and gram negative human pathogenic bacteria. Here kanamycin disc $(30 \mu \mathrm{g} / \mathrm{disc})$ was used as standard. The chloroform extract of Coccinia cordifolia showed good antibacterial activity with the average zone of inhibition $9-12 \mathrm{~mm}$. The n-hexane and ethyl acetate extract showed average zone of inhibition $7-10 \mathrm{~mm}$ and $7-11 \mathrm{~mm}$ respectively. The Brine shrimp lethality bioassay method was used to determine the cytotoxic activity and vincristine sulphate was used as positive control. The $\mathrm{LC}_{50}$ values of standard vincristine sulphate, chloroform, $\mathrm{n}$-hexane and ethyl acetate extract were $7.55 \mu \mathrm{g} / \mathrm{ml}, 23.96 \mu \mathrm{g} / \mathrm{ml}, 14.12 \mu \mathrm{g} / \mathrm{ml} \& 15.49 \mu \mathrm{g} / \mathrm{ml}$ respectively which indicate the plants extracts compounds are promisingly cytotoxic and they might have antitumer and pesticidal activity. Among the extracts the chloroform extract showed the highest cytotoxic activity with $\mathrm{LC}_{50}$ $23.96 \mu \mathrm{g} / \mathrm{ml}$. Antioxidant activity test of the crude extracts were assessed by means of DPPH free radical scavenging method where ascorbic acid was used as standard with $\mathrm{IC}_{50} 43.22 \mu \mathrm{g} / \mathrm{ml}$. The ethyl acetate fraction of Coccinia cordifolia showed strongest antioxidant activity with $\mathrm{IC}_{50}$ value of $50.98 \mu \mathrm{g} / \mathrm{ml}$.
\end{abstract}

Keywords: Coccinia cordifolia, antibacterial, antioxidant, cytotoxic.

\section{INTRODUCTION}

The antimicrobial compounds found in plants are of interest because antibiotic resistance is becoming a worldwide public health concern especially in terms of food-borne illness and nosocomial infections (Anderson et al., 2001; Hsueh et al., 2005; Lin et al., 2005; Mora et al., 2005; Navon-Venezia et al., 2005; Vattem et al., 2004). Naturally occurring antimicrobials are being sought as replacements for synthetic preservatives such as parabens (ethyl, methyl, butyl and propyl parabens), butylated hydroxytoluene (BHT) and butylated hydroxyanisole $(\mathrm{BHA})$ that are under scrutiny as suspected cancer causing agents (Bergfeld et al., 2005; Byford et al., 2002; Wangensteen et al., 2004). Plants produce a multitude of organic compounds that have antimicrobial activity. The compounds are found in various plant parts such as stems, roots, leaves, bark, flowers or fruits and seeds and include alliin/allicins, isothiocyanates, plant pigments (Cutter, 2000), hydrolytic enzymes, proteins, essential oils (Smid and Gorris, 1999), and phytoalexins or phenolic compounds (Cutter, 2000; Smid and Gorris, 1999).

Over 3000 species of plants with antitumour properties have been reported (Hartwell, 1982). Interesting patterns of differential cytotoxicity have been associated with known classes of compounds, such as cardenolides, lignans or quassinoids (Cardellina et al., 1993).

Oxidative stress is mediated by reactive oxygen species (ROS) which are generated during the normal and aberrant cellular metabolism that utilizes molecular oxygen. The imbalance between production of ROS and the capacity of the normal detoxification systems in favour of the oxidants lead to oxidative stress, which itself leads to cellular damage caused by the interaction of ROS with cellular constituents. Oxidative stress is involved in many acute and chronic diseases including cancer, cardiovascular troubles and neurodegenerative diseases. The balance between antioxidation and oxidation is believed to be critical in maintaining a healthy biological system (Hong \& Liu, 2004; Judge, 
Jang, Smith, Hagen, \& Leeuwenburgh, 2005; Katalinic, Milos, Kulisic, \& Jukic, 2006; Montuschi, Barnes, \& Roberts, 2004; Pak et al., 2006). Recently, many researchers have taken a great interest in medicinal plants for their phenolic concentrations and related total antioxidant potential (Djeridane et al., 2006; Katalinic et al., 2006; Wong, Li, Cheng, \& Chen, 2006). It is reported that some medicinal plants contain a wide variety of natural antioxidants, such as phenolic acids, flavonoids and tannins, which possess more potent antioxidant activity than dietary plants (Wong et al., 2006). Many investigations indicate that these compounds are of great value in preventing the onset and/or progression of many human diseases (Halliwell \& Gutteridge, 1989; Halliwell, Gutteridge, \& Cross, 1992). The healthpromoting effect of antioxidants from plants is thought to arise from their protective effects by counteracting reactive oxygen species (ROS) (Wong et al., 2006).

The objective of the present study was to investigate the antibacterial, cytotoxic and antioxidant activity of the different fractions of Coccinia cordifolia. Therefore, systematic research with medicinal plants may open the door of many therapeutic choices.

The leaves of Coccinia cordifolia contain triterpenoids, alkaloids and tannins (Rastogi RP et al., 1990).Green fruit when chewed cures sores on tongue; raw fruit used as vegetable; dried fruit removes eczema. Dried bark has cathartic properties. Root is used to remove pain in joints, diabetes, skin lesions (Tenia), apthous ulcers, wheezing and phlegm (Syed Zeenat et al.,2009). The roots, stems, leaves and whole plants are used in the treatment of jaundice, bronchitis, skin eruptions, burns, insect bites, fever, indigestion, nausea, eye infections, allergy, syphilis, gonorrhoea, etc (M. Umamaheswari et al.,2008). The leaves of the plant possess antidiabetic, antiinflammatory, antipyretic, analgesic, antispasmodic, antimicrobial, cathartic, expectorant activities (Asolkar LV et al. : Nadkarni KM et al., 1992). Every part of this plant is valuable in medicine for ring worm, psoriasis, small pox, scabies (Perry, 1980) and other itchy skin eruptions and ulcers (Behl et al., 1993). Coccinia cordifolia has antidiabetic (Purintrapiban et al., 2006), hypoglycemic (Akhtar et al., 2007), anti-inflammatory (Rao et al., 2003; Juneja et al., 2007), analgesic (Rao et al., 2003), hepatoprotective (Rao et al., 2003), antioxidant (Venkateshwaran and Pari, 2003), antilitihic (Jayaweera, 1980), and antimutagenic (Kusamran et al.,1998) activities. Oil of this plant is used as an injection into chronic sinuses. The plant is used in decoction for gonnorhoeae (Nadkarni, 1976), diabetes and also useful in dropsical condition, pyelitis, cystitis, strangury, snake bite, urinary gravel and calculi (Jayaweera, 1980; Nadkarni, 1976).

\section{MATERIALS AND METHODS}

Plant material: The fresh leaf of Coccinia cordifolia was collected from Daulatpur, Kushtia in the month of January 2010 and identified by Dr. M. A. Razzaque Shah, Tissue Culture Specialist, BRAC Plant Biotechnology Laboratory, Dhaka, Bangladesh.

Plant materials extraction and fractionation: The fresh leaf was collected, sun dried for seven days and ground. The dried powder of Coccinia cordifolia leaf $(200 \mathrm{gm})$ was soaked in $600 \mathrm{ml}$ of methanol for 7 days and filtered through a cotton plug followed by Whatman filter paper number 1 . The concentrated ethanolic extract of leaf (16 gm) was fractionated by the modified Kupchan partitioning method (Van Wagenen et al., 1993) into n-hexane, chloroform and ethyl acetate. The subsequent evaporation of solvents afforded n-hexane (450 mg), chloroform $(700 \mathrm{mg})$ and ethyl acetate $(350 \mathrm{mg})$ from leaf extract.

Antibacterial assay: The disc diffusion method (Bauer et al., 1966) was used to test antimicrobial activity against eleven bacteria. Solutions of known concentration $(\mathrm{mg} / \mathrm{ml})$ of the test samples were made by dissolving measured amount of the samples in calculated volume of solvents. Dried and sterilized filter paper discs $(6 \mathrm{~mm}$ diameter $)$ were then impregnated with known amounts of the test substances using micropipette. Discs containing the test materials were placed on nutrient agar medium uniformly seeded with the pathogenic test microorganisms. Standard antibiotic discs (Kanamycin 30 $\mathrm{\mu g} / \mathrm{disc}$ ) and blank discs (impregnated with solvents) were used as a positive and negative control. These plates were then kept at low temperature $\left(4^{\circ} \mathrm{C}\right)$ for $24 \mathrm{hrs}$ to allow maximum diffusion. The plates were then incubated at $37^{\circ} \mathrm{C}$ for $24 \mathrm{hrs}$ to allow maximum growth of the organisms. The test materials having antibacterial activity inhibited the growth of the microorganisms and a clear, distinct zone of inhibition was visualized surrounding the medium. The antibacterial activity of the test agent was determined by measuring the diameter of zone of inhibition expressed in millimeter. The experiment was carried out three times and the mean of the reading is required (Bauer et al., 1966). The antibacterial activity of $n$-hexane, chloroform and ethyl acetate of leaf was determined at a concentration of $500 \mu \mathrm{g} / \mathrm{disc}$. 
Cytotoxicity Screening: Brine shrimp lethality bioassay is widely used in the bioassay for the bioactive compounds (Meyer et al., 1982; Zhao et al., 1992). Here simple zoological organism (Artemia salina) was used as a convenient monitor for the screening. The eggs of the brine shrimp were collected from an aquarium shop (Dhaka, Bangladesh) and hatched in artificial seawater (3.8\% $\mathrm{NaCl}$ solution) for $48 \mathrm{hrs}$ to mature shrimp called nauplii. The cytotoxicity assay was performed on brine shrimp nauplii using Meyer method (Meyer et al., 1982). The test samples (extract) were prepared by dissolving them in DMSO (not more than $50 \mu$ in 5 $\mathrm{ml}$ solution) plus sea water $(3.8 \% \mathrm{NaCl}$ in water) to attain concentrations of $5,10,20,40$, and $80 \mu \mathrm{g} / \mathrm{ml}$. A vial containing $50 \mu \mathrm{l}$ DMSO diluted to $5 \mathrm{ml}$ was used as a control. Standard Vincristine sulphate was used as positive control. Then matured shrimps were applied to each of all experimental vials and control vial. After 24 hours, the vials were inspected using a magnifying glass and the number of survived nauplii in each vial was counted. From this data, the percent (\%) of lethality of the brine shrimp nauplii was calculated for each concentration.

Screening for antioxidant activity: Antioxidant activity of n-hexane, chloroform and ethyl acetate of leaf extracts of Coccinia cordifolia was determined on the basis of their scavenging potential of the stable DPPH free radical in both qualitative and quantitative assay.

Qualitative assay: A suitable diluted stock solutions were spotted on pre-coated silica gel TLC plates and the plates were developed in solvent systems of different polarities (polar, medium polar and nonpolar) to resolve polar and non-polar components of the extracts. The plates were dried at room temperature and were sprayed with $0.02 \% \mathrm{DPPH}$ in ethanol. Bleaching of DPPH by the resolved band was observed for 10 minutes and the color changes (yellow on purple background) were noted (Sadhu et al., 2003).

Quantitative assay: The antioxidant activity of leaf extract of Coccinia cordifolia was determined using the 1, 1-diphenyl-2-picrylhydrazyl (DPPH) free radical scavenging assay by the method of Blois (1958). DPPH offers a convenient and accurate method for titrating the oxidizable groups of natural or synthetic anti-oxidants (Cao et al., 1997). DPPH solution was prepared in $95 \%$ methanol. The crude extracts of Coccinia cordifolia were mixed with $95 \%$ methanol to prepare the stock solution $\left(5 \mathrm{mg} 50 \mathrm{~mL}^{-1}\right)$. The concentration of the sample solutions was $100 \mu \mathrm{gL} \mathrm{m}^{-}$ ${ }^{1}$. The test samples were prepared from stock solution by dilution with methanol to attain a concentration of $20 \mu \mathrm{g} / \mathrm{ml}, 40 \mu \mathrm{g} / \mathrm{ml}, 60 \mu \mathrm{g} / \mathrm{ml}, 80 \mu \mathrm{g} / \mathrm{ml}$ $\& 100 \mu \mathrm{g} / \mathrm{ml}$ respectively. Freshly prepared DPPH solution was added in each of these test tubes containing leaf extracts of Coccinia cordifolia and after $20 \mathrm{~min}$, the absorbance was taken at $517 \mathrm{~nm}$. Ascorbic acid was used as a positive control. The DPPH solution without sample solution was used as control. 95\% methanol was used as blank. Percent scavenging of the DPPH free radical was measured using the following equation-

$\%$ DPPH radical scavenging $(\%)=[1-($ As/Ac $)] \times 100$.

Here, Ac =absorbance of control, As =absorbance of sample solution.

Then \% inhibitions were plotted against respective concentrations used and from the graph $\mathrm{IC}_{50}$ was calculated.

\section{RESULT AND DISCUSSION:}

The Results of Antibacterial Screening: The results of the extracts displaying antibacterial effect against different bacteria are shown in Table 1. The Chloroform extract of Coccinia cordifolia showed the highest $12 \mathrm{~mm}$ zone of inhibition against gram positive bacteria Sarcina lutea and Bacillus subtilis and an average zone of inhibition was $9 \mathrm{~mm}$ to 12 $\mathrm{mm}$. The ethyl acetate extract was also active in varying degrees. $7 \mathrm{~mm}$ to $11 \mathrm{~mm}$ zone of inhibition was showed by the ethyl acetate extract and the highest zone of inhibition $11 \mathrm{~mm}$ was showed against Staphylococcus aureus, a gram positive bacterium. The n-hexane extract showed the highest $10 \mathrm{~mm}$ zone of inhibition against gram positive bacteria Sarcina Lutea and gram negative bacteria Pseudomonas aeruginosa.

The Results of Cytotoxicity Test: The crude chloroform, n-hexane, ethyl acetate extract of Coccinia cordifolia showed better cytotoxic activity with $\mathrm{LC}_{50}$ values of $23.96 \mu \mathrm{g} / \mathrm{ml}, 14.12 \mu \mathrm{g} / \mathrm{ml}$, $15.49 \mu \mathrm{g} / \mathrm{ml}$ in comparision with vincristine sulphate as standard whose $\mathrm{LC}_{50}$ value is $7.55 \mu \mathrm{g} / \mathrm{ml}$.

The Results of Antioxidant Activity Test: DPPH is one of the free radicals widely used for testing preliminary radical scavenging activity of a compound or a plant extract.

Qualitative assay: The color changes (yellow on purple background) on the TLC plates were observed due to the bleaching of DPPH by the resolved bands.

Quantitative assay: The crude chloroform, Nhexane, ethyl acetate extract of Coccinia cordifolia showed better antioxidant activity with $\mathrm{IC}_{50}$ values of $56.98 \mu \mathrm{g} / \mathrm{ml}, 51.33 \mu \mathrm{g} / \mathrm{ml}, 50.98 \mu \mathrm{g} / \mathrm{ml}$ in comparison 
Agric. Biol. J. N. Am., 2011, 2(4): 713-719

with ascorbic acid as standard whose $\mathrm{IC}_{50}$ value $43.22 \mu \mathrm{g} / \mathrm{ml}$.

Table 1: In vitro antibacterial activity of the extracts of Coccinia cordifolia (leaves) and standard kanamycin discs.

\begin{tabular}{|c|c|c|c|c|}
\hline Test organism & \multicolumn{4}{|c|}{ Diameter of Zone of inhibition } \\
\hline Staphylococcus aureus & 11 & 11 & 8 & 33 \\
\hline Bacillus subtilis & 10 & 9 & 8 & 30 \\
\hline Bacillus megaterium & 9 & 8 & 9 & 32 \\
\hline Vibrio parahemolyticus & 11 & 8 & 8 & 32 \\
\hline Salmonella typhi & 10 & 7 & 7 & 32 \\
\hline Shigella dysenteriae & 10 & 8 & 7 & 28 \\
\hline Shigella boydii & 9 & 7 & - & 30 \\
\hline Pseudomonas aeruginosa & 12 & 8 & 10 & 28 \\
\hline
\end{tabular}

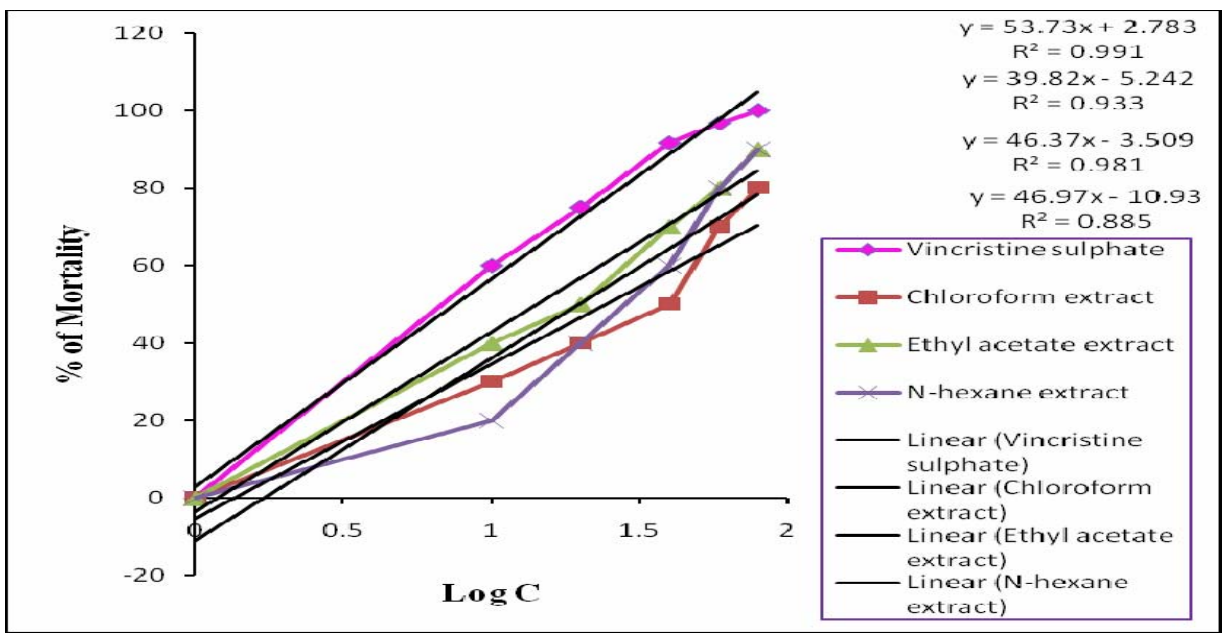

Fig 1: Determination of $\mathrm{LC}_{50}$ values for standard and crude chloroform, $n$-hexane, and ethyl acetate extracts of leaves Coccinia cordifolia from linear correlation between logarithms of concentration versus percentage of mortality. 


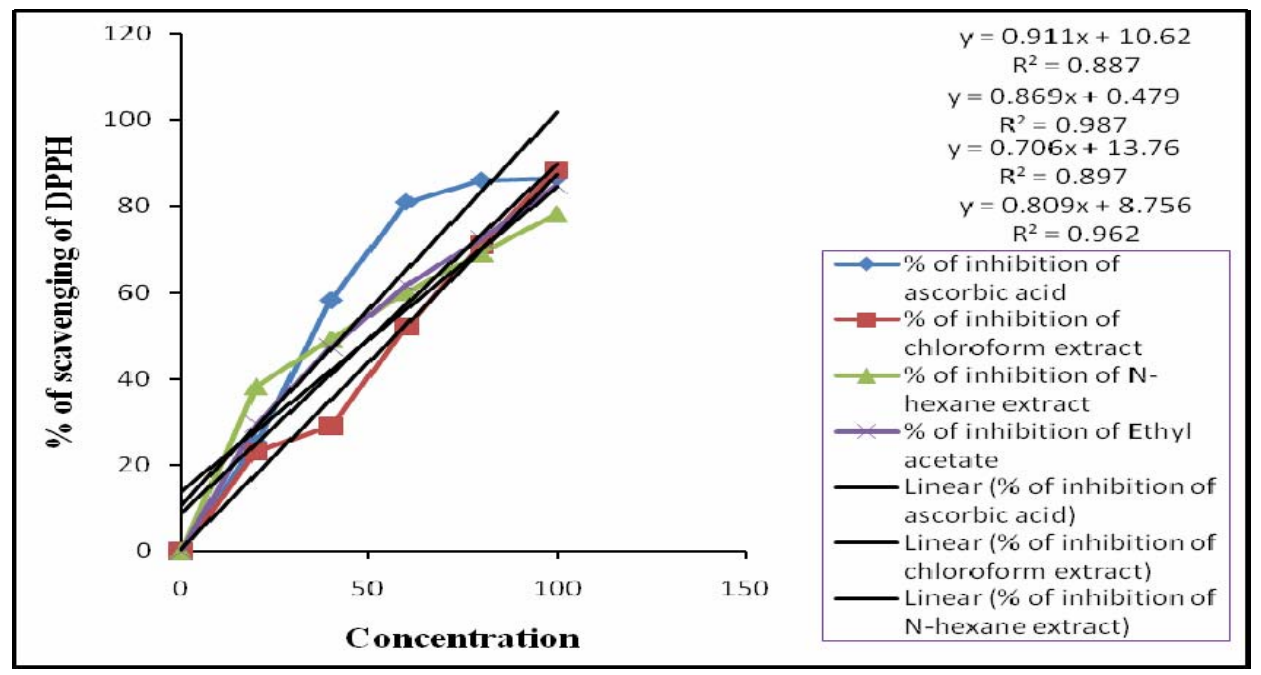

Fig 2: Determination of $\mathrm{IC}_{50}$ value for standard and crude chloroform, $\mathrm{n}$-hexane, ethyl acetate extracts of leaves of Coccinia cordifolia from linear correlation between concentrations $(\mu \mathrm{g} / \mathrm{ml})$ versus percentage of scavenging of DPPH.

\section{DISCUSSION:}

The chloroform extract of the plant showed moderate antibacterial activity with $12 \mathrm{~mm}$ zone of inhibition against gram positive bacteria Sarcina lutea and Bacillus subtilis. The ethyl acetate extract showed $11 \mathrm{~mm}$ zone of inhibition against Staphylococcus aureus, a gram positive bacterium and n-hexane extract showed $10 \mathrm{~mm}$ zone of inhibition against gram positive bacteria Sarcina Lutea and gram negative bacteria Pseudomonas aeruginosa. All the fractions showed antibacterial activity against all the organisms with average zone of inhibition $7 \mathrm{~mm}$ to $12 \mathrm{~mm}$, except $\mathrm{n}$-hexane extract showed no activity against Shigella boydii. Since the pure compound show more antibacterial activity then the lead compound isolation will be our next concern.

In comparison with the standard (vincristine sulphate), the $n$-hexane and ethyl acetate of the plant extracts compound are promisingly cytotoxic and they might have antitumor or pesticidal activity. Among the extracts chloroform extract showed highest citotoxic potential with $\mathrm{LC}_{50}$ values $23.96 \mu \mathrm{g} / \mathrm{ml}$. So, these cytotoxic samples may have clinical and therapeutic proposition in the most life threaten diseases like tumor or cancer and further studies are required to investigate these plant samples as antineoplastic agents.

The ethyl acetate extract of coccinia cordifolia showed strongest antioxidant activity with $\mathrm{IC}_{50}$ value $50.98 \mu \mathrm{g} / \mathrm{ml}$ and other showed good antioxidant activity. As mentioned, the Reactive Oxygen Species (ROS) or oxidants, which are formed in the human body due to exogenous and endogenous factors, are found to be responsible for many diseases. Day by day, a lot of researches have shown the potential of phytochemical antioxidants as health benefactors because of their ability to neutralize free radicals, reactive oxygen species, or oxidants responsible for the onset of cell damage.

\section{CONCLUSION:}

So it may be concluded that Coccinia cordifolia is active against tested pathogenic bacteria and also have cytotoxic and antioxidant effects. Therefore, those might be utilized for the development traditional medicines and further investigation should be necessary for the development of novel lead compound.

\section{REFERENCE:}

Afia Akhtar M, Mamunur R, Mir Imam IW, Robiul IM, Sharif MS, Ariful IMd, Shah AMd, Maruf A (2007). Comparision of Long - term Antihyperglycemic and Hypolipidemic Effects between Coccinia cordifolia (Linn.) and Catharanthus roseus (Linn.) In Alloxan induced diabetic Rats. Res. J. Med. Sci. 2: 29-34.

Anderson Jr. ER, Koplan J, Henney JE, Billy TJ (2001). Diagnosis and Management of Foodborne Illness: A Primer for Physicians. Centers for Disease Control, Morbidity and Mortality Weekly Report50 (RR02), 1-69.

Asolkar LV, Kakkar KK, Chakre OJ. Second supplement to Glossary of Indian Medicinal Plants with Active Principles Part-I (A-K). Council of Scientific and Industrial Research (PID) (Part- I), New Delhi, 1992; pp. 217-218. 
Bauer A.W., W.M. M. Kirby, J.C. Sherries and M. Tuck, 1966. "Antibiotic susceptibilitytesting by a standardized disc diffusion method", American Journal of Clinical Pathology 45 pp. 493-496.

Behl PN, Arora RB, Srivastava G, Malhotia (1993). Herbs useful in Dermatological therapy, CBS Publishers and Distributor, Delhi.

Bergfeld, Wilma F, MD, Donald V. Belsito, MD, James G. Marks, Jr ,MD, F Alan Andersen. (2005). Safety of ingredients used in cosmetics.J. Am. Acad. Dermatol. 52:125-132.

Blois, M.S. 1958. Antioxidant determinations by the use of a stable free radical, Nature, 181: 1199- 1200.

Byford JR, Shaw LE, Drew MGB, Pope GS, Sauer MJ, Darbre PD (2002). Oestrogenic activity of parabens in MCF7 human breast cancer cells. J. Steroid Biochem. Mol. Biol. 80:49-60.

Cao, G., E. Sofic and R.L. Prior, 1997. "Antioxidant and prooxidant behaviour of flovonoids:structure activity relationmships", Free radical Biologt \& Medicine 22, pp. $759-760$

Cardellina JH, Gustafson KR, Beutler JA. 1993. NCl intramural research on HIV inhibitory and antitumor plant natural products. In Human Medicinal Agents from Plants. Kinghorn AD, Balandrin MF (eds) Am Chem Soc Symp Ser 534. ACS: Washington, DC; $218 \pm 227$.

Cutter C (2000). Antimicrobial effect of herb extracts against Escherichia coli 0157:h7, Listeria monocytogenes and Salmonella typhimurium associated with beef. J. Food Prot. 63:601-607.

Djeridane, A., Yousfi, M., Nadjemi, B., Boutassouna, D., Stocker, P., \& Vidal, N. (2006). Antioxidant activity of someAlgerian medicinal plants extracts containing phenolic compounds. Food Chemistry, 97, 654-660.

Halliwell, B.., \& Gutteridge, J. M. C. (1989) Free radicals in biology and medicine. Oxford: Clarendon Press.

Halliwell, B.., \& Gutteridge, J. M. C. \& Cross, C. E. (1992). Free radicals, antioxidants, and human disease: where are we now? Journal of Laboratory and Clinical Medicine, 119, 598-619.

Hartwell JL. 1982. Plants Used Against Cancer. A Survey. Quarterman Publications: Lawrence.

Hong, H. \& Liu, G. (2004). Protection against hydrogen peroxide induced cytotoxicity in $\mathrm{PCl} 2$ cells by scutellarin. Life Sciences, 74, 2959-2973.

Hsueh PR, Chen WH, Teng LJ, Luh KT (2005). Nosocomial infections due to methicillin-resistant Staphyloccus aureus and vancomycinresistant enterococci at a university hospital in Taiwan from 1991 to 2003: resistance trends, antibiotic usage and in vitro activities of new antimicrobial agents. Int. J. Antimicrob. Agents 26:43-49.

Jayaweera DM (1980). Medicinal Plants (Indigenous and Exotic) used in Ceylon. Part 2. A Publication of the Natural Sciences Council of Srilanka, Colombo.

Judge, S., Jang, Y.M. Smith, A., Hagen, T., \& Leeuwenburgh, C. (2005). Age associated increases in oxidative stress and antioxidant enzyme activities in cardiac interfibrillar mitochondria: implications for the mitochondrial theory of aging. The Faseb Journal, 2622-2642.

Juneja D, Shrivastava PN, Guha MK, Saxena RC (2007). PHCOG MAG.: Short communication. Preliminary Phytochemical Screening of Some Folklore Medicinal Plants for their anti-inflammatory activity. Phcog. Mag. Issue 11 (Suppl.) Jul- Sep.pp. 201-203.

Katalinic, V., Milos, M., Kulisic, T., \& Jukic, M. (2006). Screening of 70 medicinal plant extracts for antioxidant capacity and total phenols. Food Chemistry, 94, 550557.

Kusamran WR, Anong T, Piengchai K (1998). Antimutagenic and anti carcinogenic potential of some Thai vegetables. Mutat. Res. 402: 247-258.

Lin YT, Vattem D, Labbe RG, Shetty K (2005). Enchancement of antioxidant activity and inhibition of Helicobacter pylori by phenolic phytochemicalenriched alcoholic beverages. Process Biochem. 40:2059-2065.

M. Umamaheswari and T. K. Chatterjee, 2008 "In vitro antioxidant activities of the fractions of coccinia grandis L. Leaf Extract.., Afr. J. Traditional,Complementary and Alternative Medicines, (000) 5 (1): 61 - 73.

Meyer, B.N., N.R. Ferrigni, J.E. Putnam, L.B. Jacobsen, D.E. Nichols and J.L. Mclaughlin, 1982. Brine shrimp: a convenient general bioassay for the active plant constituents. Planta Medicine, 45: 31-34.

Montuschi, P., Barnes, P. J., \& Roberts, L. J. (2004). Isoprostanes: markers \& mediators of oxidative stress induced cataracts. The Faseb Journal Review, 18, 1791-1800.

Mora A, Blanco JE, Blanco M, Alonso MP, Dhabi G, Echeita A, Gonzalez EA, Bernardez MI, Blanco J (2005). Antimicrobial resistance of Shiga toxin (verotoxin)-producing Escherichia coli 0157: $\mathrm{H} 7$ and non-0157 strains isolated from humans, cattle, sheep and food

Nadkarni, K.M. 1976. Indian Materia Medica with Ayurvedic, Unani Products and Home Remedies. vol. 1, Popular Prakasham, Bombay.

Nadkarni KM, Nadkarni AK. Indian Materia Medica $3^{\text {rd }}$ Ed. (Vol-I), Popular Prakashan Pvt. Ltd., Mumbai, , 1992; pp. 300-302. 
Navon-Venezia S, Ben-Ami R, Carmeli Y (2005). Update on Pseudomonas aeruginosa and Acinetobacter baumannii infections in the healthcare setting. Curr. Opin. Infect. Dis. 18: 306-313.

Pak, J.H., Kim, M.J., Kim, J. Y., Choi, H., Kim, S. A. et al. (2006). Reduced expression of 1-cys peroxiredoxin in oxidative stress-induced cataracts. Experimental Eye Research, 82, 899-906.

Perry LM (1980) Medicinal Plants of East and South East Asia, Attributed properties and Uses, MIT Press, London.

Purintrapiban J, Keawpradub N, Jansakul C (2006). Role of the water extract from Coccinia indica stem on the stimulation of glucose transport in L8 myotubes. Songklanakarin J. Sci. Technol. 28: 1199-1208.

Rao GMM, Vijayakumar M, Sreevidya N, Rao CV, Mehrotra S, Shirwaikar A (2003). Chemical and pharmacological investigation of the fruits of Coccinia indica. 2nd World Congress on Biotechnological Developments of Herbal Medicine, NBRI, Lucknow, UP, India. p. 131, February $20-22$.

Rastogi RP, Mehrotra BN. Campendium of Indian Medicinal Plants. (Vol.-I), New Delhi, 1990; pp. 115.

Sadhu, S. K.; E. Okuyama, H. Fujimoto and M. Ishibashi, 2003."Separation of Leucas aspera, a medicinal plant of Bangladesh, guided by prostaglandin inhibitory and antioxidant activities" Chemical \& Pharmaceutical Bulletin 51, pp.595-598.

Smid EJ, Gorris LGM (1999). Natural antimicrobials for food preservation. In Rahman MS (ed) Handbook of
Food Preservation, MarcelDekker, New York, pp 285308.

Syed Zeenat Shaheen, Krishna Bolla, Kandukuri Vasu and M. A. Singara Charya, 2009. Antimicrobial activity of the fruit extracts of Coccinia indica,, African Journal of Biotechnology Vol. 8 (24), pp. 7073-7076,

Van Wagenen, B.C., R. Larsen, J.H. Cardellina, D. Ran dazzo, Z.C. Lidert and C. Swithenbank, 1993. Ulosantoin, a potent insecticide from the sponge Ulosa ruetzleri. J Org Chem. 58, 335-337.

Vattem DA, Lin YT, Labbe RG, Shetty K (2004). Antimicrobial activity against select food-borne pathogens by phenolic antioxidants enriched in cranberry pomace by solid-state bioprocessing using the food grade fungus Rhizopus oligosporus. Process Biochem. 39

Venkateshwaran S, Pari L (2003). Effect of Coccinia indica leaves on antioxidant status in streptozotocin - induced diabetic rats .Journal of Ethnopharmacology 84: 163168.

Wangensteen H, Samuelsen AB, Malterud KE (2004). Antioxidant activity in extracts from coriander. Food Chem. 88: 293-297.

Wong, C., Li, H., Cheng, F. (2006). A systematic survey of antioxidant activity of 30 chinese medicinal plants using the ferric reducing antioxidant power assay. Food Chemistry, 97,705-711.

Zhao, G.X., Y.-H. Hui, J.K. Rupprecht, J.L. McLaughlin, and K.V. Wood, 1992 "Additional bioactive compounds and trilobacin, a novel highly cytotoxic acetogenin, from the bark of Asimina triloba," Journal of Natural Products,

55 ,

347-356. 